\title{
PENGEMBANGAN MEDIA PEMBELAJARAN APLIKASI MOBILE LEARNING BERSISTEM OPERASI ANDROID
}

\author{
Rachmat Efendi ${ }^{1}$, Riza Yonisa Kurniawan ${ }^{2}$ \\ Program Studi Pendidikan Ekonomi, Universitas Negeri Surabaya \\ 1'rachmatefendi16080554023@ mhs.unesa.ac.id, ${ }^{2}$ rizakurniawan@unesa.ac.id
}

\begin{abstract}
Learning media are all things used in learning activities to convey information during the learning process. This study aims to describe the feasibility of an Android mobile learning application, describe student responses to the Android mobile learning application, and evaluate student learning outcomes towards a mobile learning application with an Android operating system. Research type Research \& Development 4D model from Thiagarajan. The research method concerned only three stages, defining, designing, and developing. Material validity instrument was collected from content experts, the media, and the assessment of questions. The research output shows that the development of a mobile learning application with an Android operating system is considered very decent based on average expert validation. Mobile learning applications are considered "very good" at learning because the development that carried out can increase the interest of students in the learning process. According to the findings of the student response study, 97.53per cent of the interest in the product and the disparity in learning outcomes between the experimental group was 94.44 and the control group was 66.66 per cent.
\end{abstract}

Keywords: Mobile Learning, Learning Outcomes, Operating System, Android

\section{Pendahuluan}

Pendidikan merupakan segala situasi hidup mampu mempengaruhi proses pertumbuhan individu sebagai pengalaman belajar ketika berlangsung dalam berbagai lingkungan serta dilakukan selama hidupnya (Roesminingsih, 2016). Pendidikan juga bisa dikatakan sebagai salah satu faktor yang ikut berkontribusi dalam pengembangan Sumber Daya Manusia (SDM). Dengan pendidikan, seseorang dapat memperoleh ilmu baik secara formal maupun non formal. Di era abad 21 ini, segala sesuatu berekembang seperti halnya dengan dunia pendidikan. Perkembangan pada dunia pendidikan khususnya pada proses pembelajaran saat ini terlihat dengan munculnya banyak media pembelajaran yang bisa diaplikasikan dalam kegiatan pembelajaran. Arsyad (2014) menyebutkan bahwa media pembelajaran merupakan segala sesuatu yang digunakan pada proses pembelajaran memiliki fungsi agar penyampaian pesan atau informasi dapat diterima sehingga dapat meningkatkan hasil belajar. sedangkan Lubis \& Ikhsan (2015) menyebutkan bahwa media pembelajaran merupakan berbagai bentuk peralatan fisik komunikasi berwujud perangkat lunak dan keras bagian kecil atas teknologi pembelajaran agar wajib dibuat atau dikembangkan, dipergunakan atau dikelola pada kebutuhan pembelajaran agar mencapai efektivitas dan efisiensi dalam proses pembelajaran. Media pembelajaran yang kurang bervariatif serta kurang invatif menjadi salah satu faktor alasan peserta didik kurang tertarik dan memiliki hasil belajar yang rendah. Inovasi pada media pembelajaran sangatlah diperlukan agar mempengaruhi semangat belajar peserta didik mendapatkan hasil belajar yang baik.

Berdasarkan pra penelitian di SMAN 1 Gedangan melalui wawancara dengan guru mata pelajaran ekonomi diketahui bahwa hasil belajar peserta didik cenderung rendah. Rendahnya hasil belajar dari peserta didik ini terlihat dari rata-rata hasil belajar peserta didik

DOI: 10.33603/ejpe.v9i1.4599 
yang berda di bawah KKM. Keberhasilan belajar hanya tercapai 19\% dari 36 peserta didik yang melampaui KKM dan $81 \%$ sisanya berada sisanya berada dibawah KKM. Tidak sampai disitu, berdasarkan wawancara dengan peserta didik diketahui bahwa media pembelajaran yang digunakan di sekolah tersebut tidak sesuai dengan kebutuhan peserta didik. Media pembelajaran yang dimaksud disini yakni power point. Media pembelajaran yang disajikan kepada peserta didik cenderung monoton dan hanya berwarna hitam putih. Hal ini yang menjadikan peserta didik kurang tertarik dengan pembelajaran. Akibatnya tujuan pembelajaran ekonomi yang sebelumnya telah dirumuskan tidak tercapai secara efisien. Dari penelitian yang dilakukan oleh Delialioğlu \& Alioon (2014) peserta didik menyukai karakteristik dari mobile learning yang dapat memberi kemudahan dalam pembelajaran..

Permasalahan yang ada di SMAN 1 Gedangan tersebut dapat diatasi dengan adanya sebuah media pembelajaran yang sesuai dengan kebutuhan peserta didik. Dimana media pembelajaran tersebut menyajikan gambar dan warna yang menarik minat peserta didik untuk belajar yang mana penyajiannya menggunakan perangkat mobile untuk meningkatkan hasil belajar peserta didik. Media pembelajaran berupa aplikasi mobile learning beroperasi sistem android (Handayani, 2016) (Kurniawati \& Nita, 2018).

Mobile learning termasuk bagian tindakan kreatif serta interaktif pada proses pembelajaran agar peserta didik bahagia dan antusias pada proses pembelajaran (Wahyono, 2018). Android termasuk sistem operasi sumber terbuka berarti gratis dan bebas digunakan oleh pengembang aplikasi, hal ini sangat memudahkan pengembang aplikasi android (Alhafidz \& Haryono, 2018) . Sedangkan menurut Quinn, (2012) Mobile learning adalah sebuah persimpangan komputasi mobile serta e-learning dimana sumber daya yang dapat diakses dimanapun dan kapanpun pengguna berada, kemanapun pencarian yang kuat, interaksi yang kaya, dan penilaian berbasis kinerja. E-learning independen dari lokasi dalam waktu dan ruang. Menurut Darmawan (2016) Mobile learning memiliki manfaat untuk peserta didik yakni mampu meningkatkan kemampuan berkomunikasi dengan guru dan peserta didik lainnya, memiliki materi pembelajaran yang telah tersaji dapat diakses tidak ada batas tempat dan waktu, dan berbagai pengetahuan dan materi yang terorganisasi dalam satu tempat materi pembelajaran online.

Android merupakan suatu sistem operasi pada perangkat mobile berbasis linux meliputi sistem operasi, middleware, dan aplikasi (Safaat H, 2012). Google membuat sumber terbuka yang dibutuhkan oleh perangkat elektronik android dengan gratis untuk semua orang yang ingin menulis kode dan mengembangkan sistem operasi android tersebut (Chryssa, 2016). Menurut Sutarsih \& Hassyati (2018) sebanyak 73,56\% dari 651 SMA s-Indonesia telah mengizinkan penggunaan telepon seluler dalam kegiatan proses pembelajaran yang menggunakan teknologi telepon seluler pintar atau smartphone.

Dari uraian permasalahan yang disebutkan mendorong peneliti melakukan penelitian berupa pengembangan media pembelajaran mobile learning bersistem operasi android. Tujuan dari penelitian ini yakni mendeskripsikan kelayakan aplikasi yang dikembangkan, mendeskripsikan respons, dan menganalisis hasil belajar peserta didik terhadap penerapan aplikasi yang telah dikembangkan.

\section{Metode Penelitian}

Jenis penelitian ini merupakan Research and Development $(R \& D)$ mengadaptasi model pengembangan 4D dari Thiagarajan, Samuel, dan Semmel (1974). Prosedur penelitian ini 
dimulai dari analisis awal, membuat rancangan produk, dan berhenti pada pengembangan. Berikut gambaran prosedur penelitian yang digunakan.

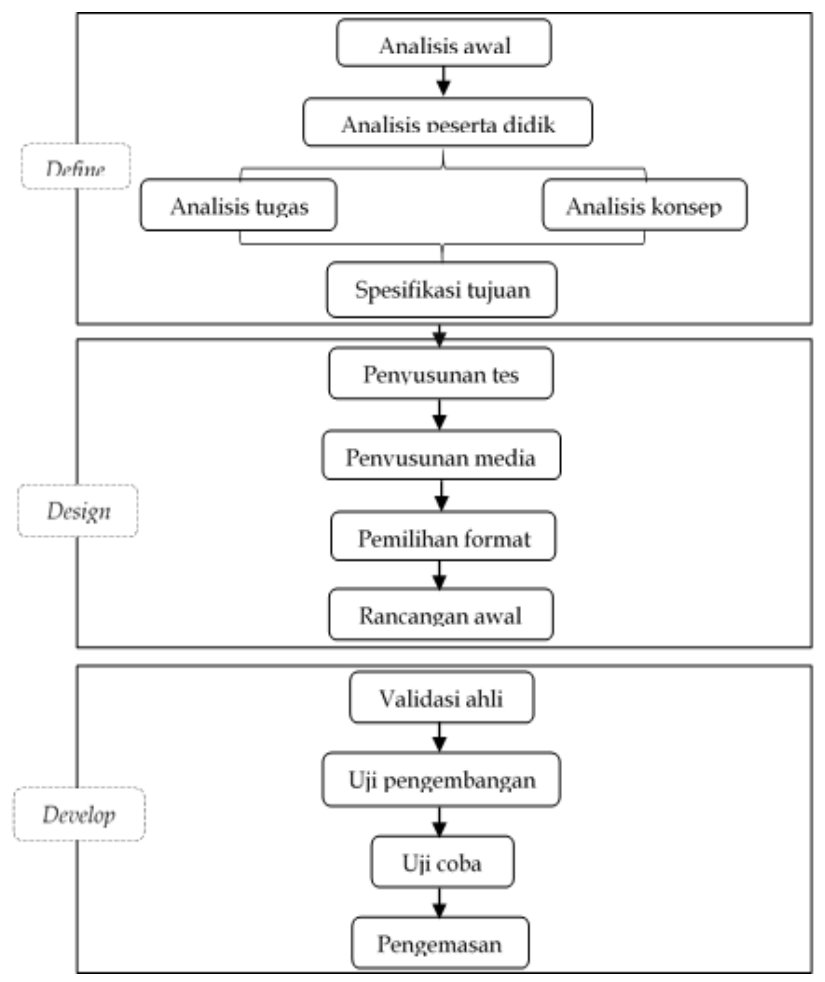

Gambar 1. Prosedur Penelitian

Desain uji coba menggunakan pra dan post-eksperimen design. Dalam uji coba ini dilakukan dengan menggunakan kelompok eksperimen dan kelompok kontrol. Hasil pengaruh variabel evaluasi akan dapat diketahui melalui hasil selisih nilai post-eksperimen dari kedua kelompok (Sugiyono, 2016).

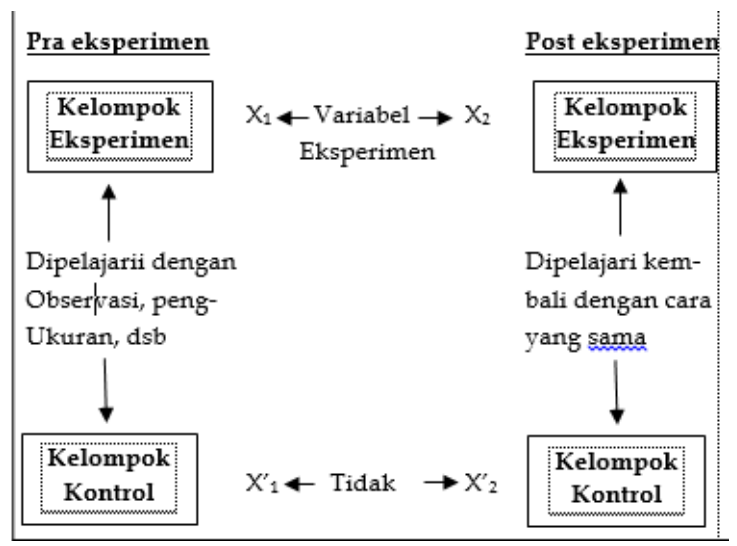

Gambar 2. Model Uji Coba
Peserta didik kelas X IPS 1 SMAN 1 Gedangan adalah populasi dalam penelitian ini dengan jumlah 36 peserta didik. Dengan mengambil subjek uji coba kelas X IPS 1 yang berjumlah 18 peserta dididk untuk melaksanakan pengukurn hasil belajar menggunakan media pembelajaran ini. Pengumpulan data menggunakan instrumen telaah produk, validasi, angket respons siswa dan tes tulis. Teknik analisis data telaah menggunakan desktiptif kualitatif, validasi ahli dan respons siswa menggunakan Skala Likert yang diinterpretasikan pada kriteria yang telah dibuat (Riduwan, 2018). Penelitian menggunakan analisis kualitatif dan kuantitaif (Riduwan, 2018). Analisis kualitatif berdasar 
hasil observasi, wawancara sedangkan kuantitatif berdasarkan kuisioner (Riduwan, 2018). Analisis hasil belajar siswa menggunakan ketuntasan klasikal dengan rentang nilai > 75 dikatakan efektif (Riduwan, 2018).

\section{Hasil dan Pembahasan}

Proses pengembangan aplikasi mobile learning bersistem operasi android menggunakan model 4D dari Thiagarajan yang terdiri dari 4 tahap yaitu define, design dan develop.

A. Tahapan pertama yakni define yang bertujuan untuk menetapkan dan menjabarkan syarat - syarat dalam pembelajaran yang terdiri dari lima langkah pokok. Tahap define terdapat 5 langkah harus dilaksanakan.

1. Pertama analisis ujung depan bertujuan agar menentukan masalah pokok dalam pembelajaran pada kelas X IPS 1 SMAN 1 Gedangang yaitu LCD kurang memenuhi untuk diterapkan keseluruh kelas dikarenakan jumlah media tersebut yang disediakan oleh sekolah terbatas. Satu buku untuk satu bangku yang terdiri dari dua peserta didik dan tidak boleh untuk dibawa pulang. Hal ini tentu menjadi kendala dalam pembelajaran yang terdampak pada rendahnya hasil belajar peserta didik di kelas X IPS 1 (Aisyah, Jaenudin, \& Koryati, 2017).

2. Kedua analisis peserta didik bertujuan pada menganalisis karakter peserta didik ketika pembelajaran ekonomi di kelas. Peserta didik ternyata menyukai media pembelajaran berbasis teknologi karena mereka mencari informasi pada smartphone masing masing daripada buku ketika mengalami kesulitan dalam mengerjakan tugas.

3. Ketiga analisis tugas bertujuan untuk menentukan tugas yang akan digunakan dalam pengembangan aplikasi mobile learning, materi yang digunakan $\mathrm{KD} \quad 3.8$ Mendeskripsikan Perkoperasian dalam perekonomian Indonesia. Penugasan terdiri dari 25 soal pilihan ganda.

4. Keempat menganalisis konsep bertujuan pada mengetahui kecocokan antara aplikasi mobile learning dikembangkan dengan materi akan diterapkan oleh peneliti supaya tujuan pembelajaran mampu tercapai.

5. Kelima tahap merumuskan hasil pembelajaran. perumusan hasil pembelajaran disesuaikan dari media pembelajaran dikembangkan dengan kompetensi dasar dan indikator pencapaian komperensi sehingga tidak keluar dari tujuan awal.

B. Tahapan kedua yakni design atau perancangan. Tahap perancangan ini dilakukan dengan tujuan untuk merancang aplikasi mobile learning yang dikembangkan. Kegiatan yang dilakukan dalam tahap perancangan adalah sebagai berikut :

1. Menentukan jenis aplikasi mobile learning. Aplikasi mobile learning dirancang sesuai dengan kebutuhan peserta didik yang digunakan sebagai media pembelajaran. Aplikasi mobile learning dapat dibuka melalui smartphone bersistem operasi Android dan diakses secara offline.

2. Menentukan judul aplikasi mobile learning. Judul aplikasi mobile learning dirancang sesuai dengan kompetensi dasar yang akan dicapai oleh peserta didik. Judul aplikasi mobile learning yang dikembangkan yakni "KIPER ekonomi koperasi".

3. Menyusun materi. Materi yang yang disusun pada aplikasi mobile learning ini sesuai KD 3.8 Perkoperasian dalam perekonomian Indonesia. Dalam materi ini terdiri terdapat beberapa pokok bahasan yaitu : sejarah, pengertian, perangkat dan organisasi koperasi, pendirian koperasi sekolah dan menghitung Sisa Hasil Usaha (SHU). 
4. Perancangan desain awal aplikasi. Rancangan format aplikasi mobile learning yang dikembangkan adalah sebagai berikut:

a. Ukuran aplikasi mobile learning. Ukuran dari tampilan aplikasi mobile learning menyesuaikan layar smartphone.

b. Desain Halaman Beranda. Struktur desain halaman beranda aplikasi mobile learning sebagai berikut :

1) Warna latar belakang beranda di dominasi warna merah dan putih.

2) Terdapat logo dan nama dari aplikasi mobile learning.

3) Terdapat 5 clickbait yang mengarahkan ke materi yang tersaji pada aplikasi mobile learning.

4) Pada bagian bawah terdapat menu petunjuk, kompetensi, beranda, kalkulator SHU, dan permainan.

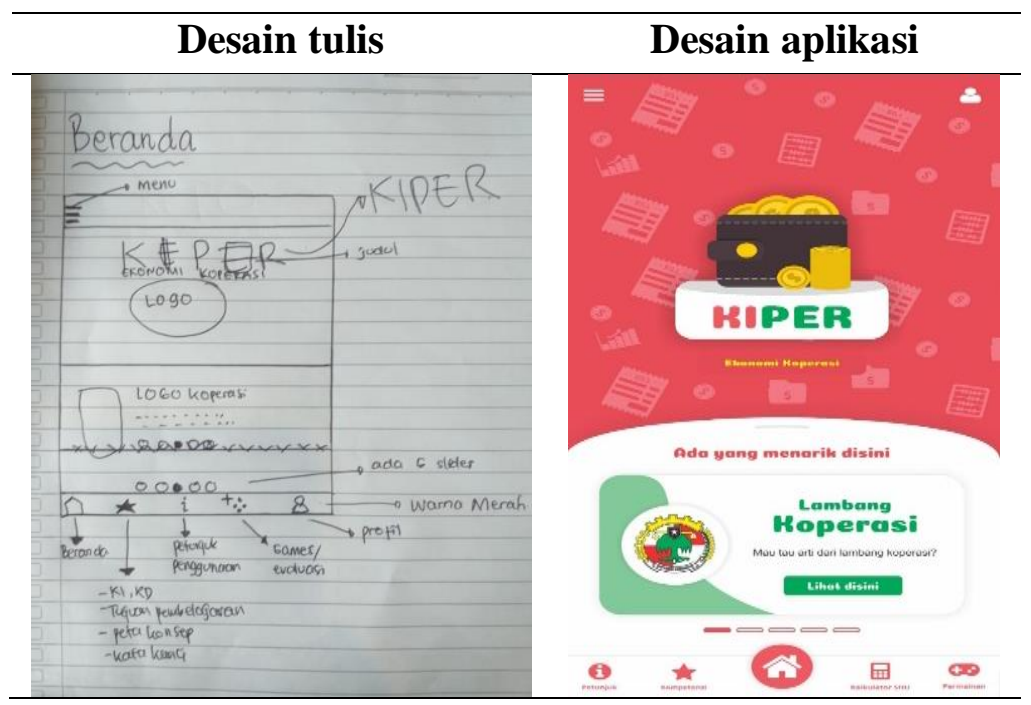

Gambar 3. Design Beranda

c. Menu Materi. Menu materi pada aplikasi mobile learning berisi tentang materi materi yang akan dipilih atau dibuka oleh pengguna aplikasi.

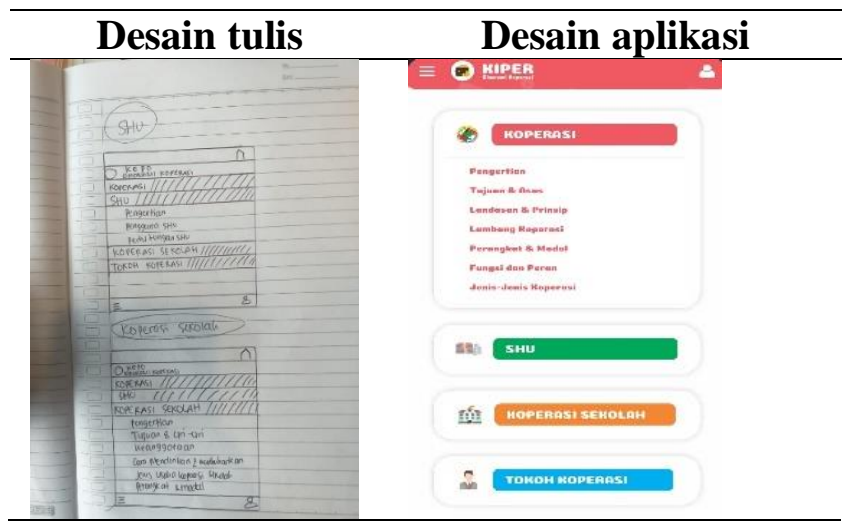

Gambar 4. Design Menu 
d. Tujuan Pembelajaran. Pada aplikasi mobile learning terdapat tujuan pembelajaran agar peserta didik mengetahui tujuan pembelajaran yang harus dicapai. Berikut merupakan tujuan pembelajaran.

e. Peta Konsep. Peta konsep pada aplikasi mobile learning berisi terkait peta atau bagan materi yang akan dipelajari oleh peserta didik secara umum. Berikut ini merupakan peta konsep pada aplikasi mobile learning.

f. Petunjuk Penggunaan aplikasi mobile learning. Di dalam aplikasi mobile learning terdapat petunjuk penggunaan yang berisi instruksi langkah - langkah yang akan dilakukan oleh peserta didik dan guru sebelum menggunakan aplikasi mobile learning untuk pembelajaran.

g. Tampilan Materi. Pada tampilan materi berisi materi yang ada pada aplikasi mobile learning dengan warna dan ilustrasi.

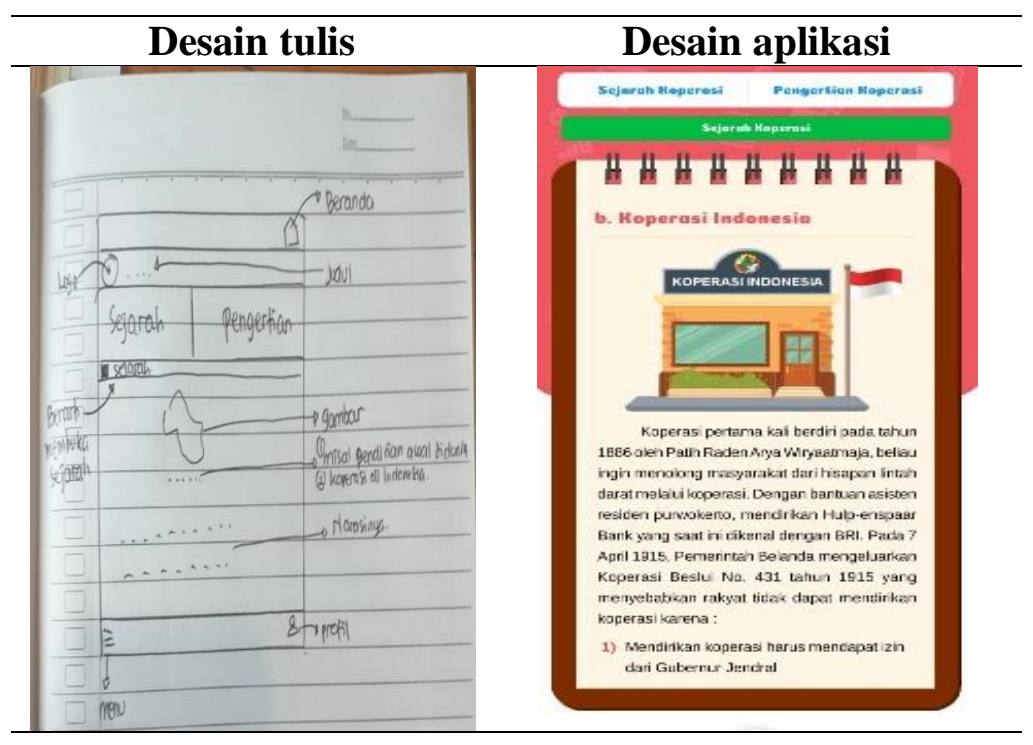

\section{Gambar 5. Desian Materi}

h. Kalkulator SHU. Di dalam aplikasi mobile learning terdapat kalkulator SHU berfungsi untuk mempermudah pengguna untuk menghitung SHU.

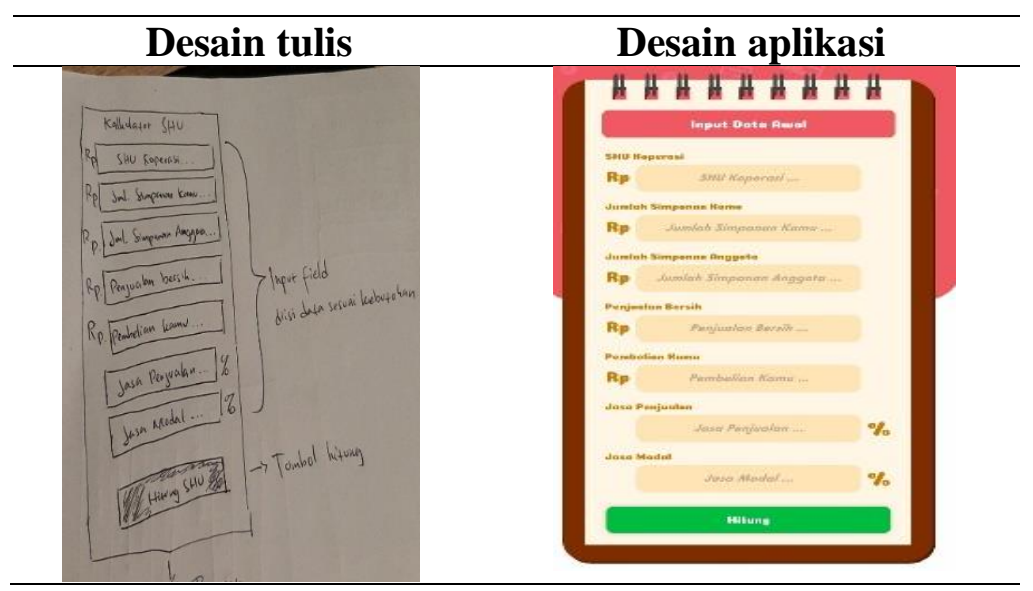

Gambar 6. Decian Kalkulator

p-ISSN 2337-571X / e-ISSN 2541-562X

(C) 2020 Edunomic: Jurnal IImiah Pendidikan Ekonomi

Fakultas Keguruan dan Ilmu Pendidikan 
i. Permainan Evaluasi. Di dalam aplikasi mobile learning terdapat permaianan evaluasi berfungsi untuk mengevaluasi pembelajaran peserta didik dengan tema yang berbeda.

C. Tahapan ketiga yakni develop atau pengembangan dilakukan dengan tujuan supaya menghasilkan produk berupa aplikasi mobile learning setelah melalui proses revisi dimana peneliti mendapat komentar serta saran perbaikan dari para ahli. Hasil telaah diperoleh dari data kualitatif dimana para ahli memberikan saran perbaikan dan komentar terhadap aplikasi mobile learning yang dikembangkan. Hasil telaah dari para ahli sebagai berikut :

\section{Hasil Telaah Ahli Materi}

Penilaian berupa telaah materi terhadap aplikasi mobile learning bertujuan untuk memperbaiki kesesuaian aplikasi mobile learning dengan silabus mata pelajaran ekonomi dalam kelengkapan materi yang disajikan dalam aplikasi mobile learning yang dikembangkan. Saran perbaikan dan komentar dari ahli materi terhadap aplikasi mobile learning yang dikembangkan adalah sebagai berikut :

\begin{tabular}{|c|c|c|}
\hline No. & Nama & $\begin{array}{c}\text { Komentar dan Saran } \\
\text { Perbaikan }\end{array}$ \\
\hline 1 & $\begin{array}{l}\text { Ahli Telaah Materi } \\
1\end{array}$ & $\begin{array}{l}\text { - Mohon ditambahkan tokoh } \\
\text { koperasi di Indonesia } \\
\text { - Mohon ditambah daftar } \\
\text { pustaka }\end{array}$ \\
\hline 2 & $\begin{array}{l}\text { Ahli Telaah Materi } \\
2\end{array}$ & $\begin{array}{llr}\text { - } & \text { Pada materi } & \text { koperasi } \\
\text { sekolah, } & \text { ditambahkan } \\
\text { perangkat dan } & \text { modal } \\
\text { koperasi sekolah } & \end{array}$ \\
\hline
\end{tabular}

Tabel 1. Telaah Ahli Materi

\begin{tabular}{|c|c|c|}
\hline $\begin{array}{c}\text { No } \\
\text {. }\end{array}$ & $\begin{array}{c}\text { Sebelum Telaah } \\
\text { Materi }\end{array}$ & Sesudah Telaah Materi \\
\hline 1 & $\begin{array}{l}\text { Tokoh koperasi di } \\
\text { Indonesia belum } \\
\text { ada } \\
\text { ada }\end{array}$ & $\begin{array}{l}\text { Tokoh koperasi di Indonesia sudah } \\
\text { ditambahkan }\end{array}$ \\
\hline
\end{tabular}




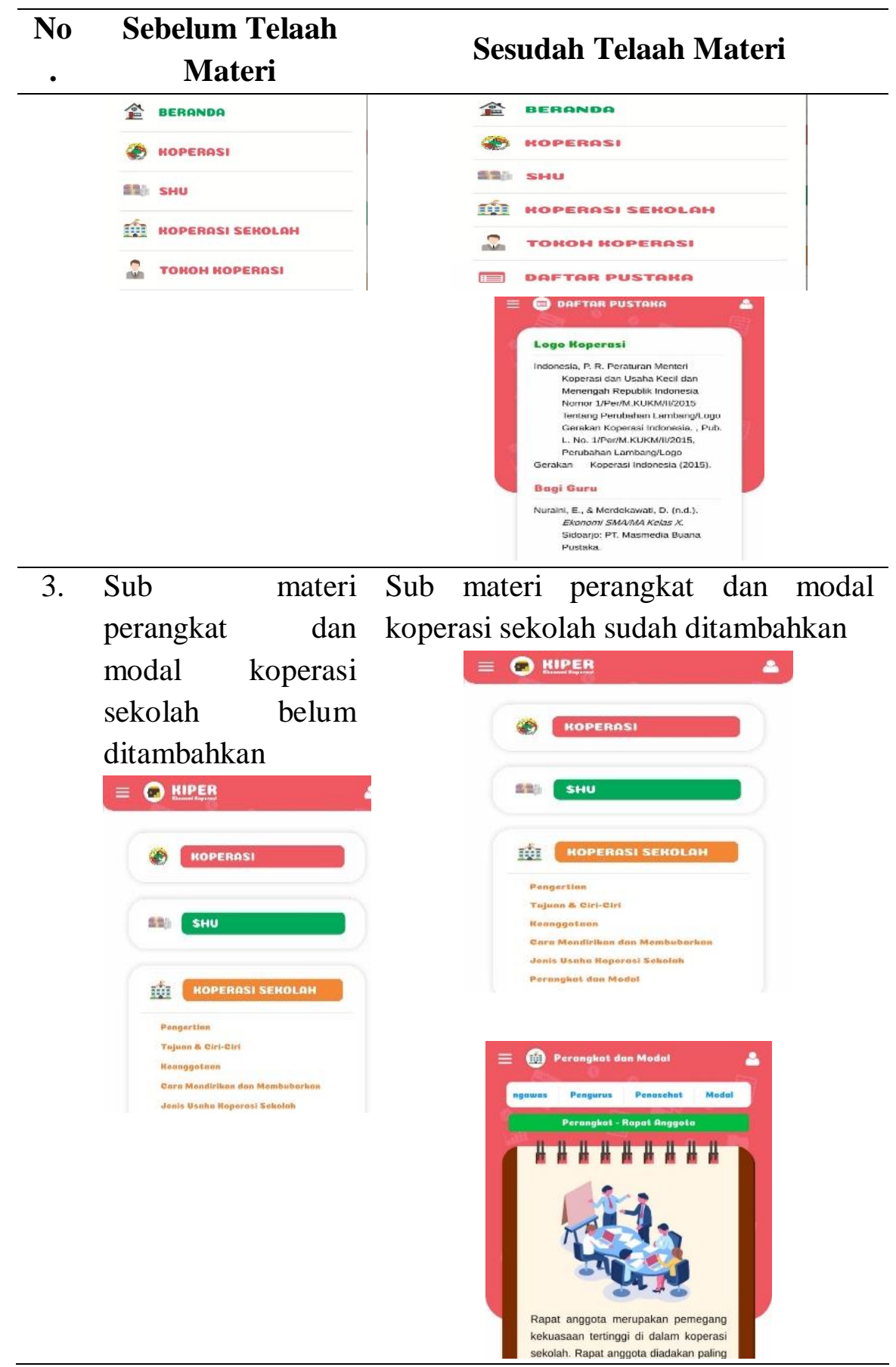

Tabel 2. Hasil Telaah Ahli Materi

\section{Hasil Telaah Ahli Media}

Penilaian berupa telaah dari ahli media dijadikan pedoman peneliti untuk memperbaiki aplikasi mobile learning yang dikembangkan. Saran perbaikan dan komentar dari ahli media sebagai berikut :

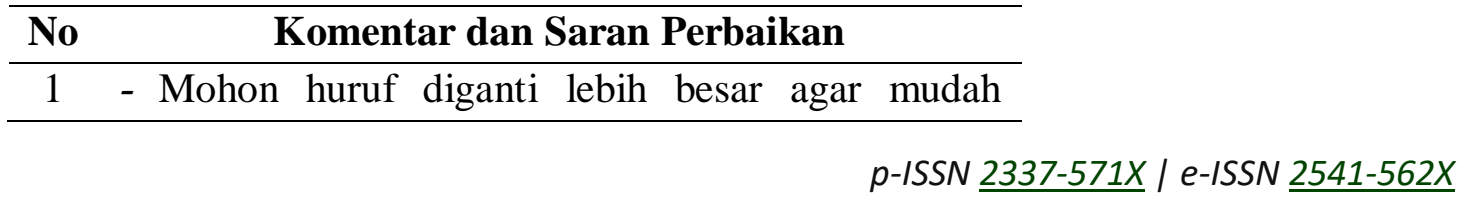


dibaca

- Mohon warna latar belakang ditajamkan

Tabel 3. Telaah Ahli Media

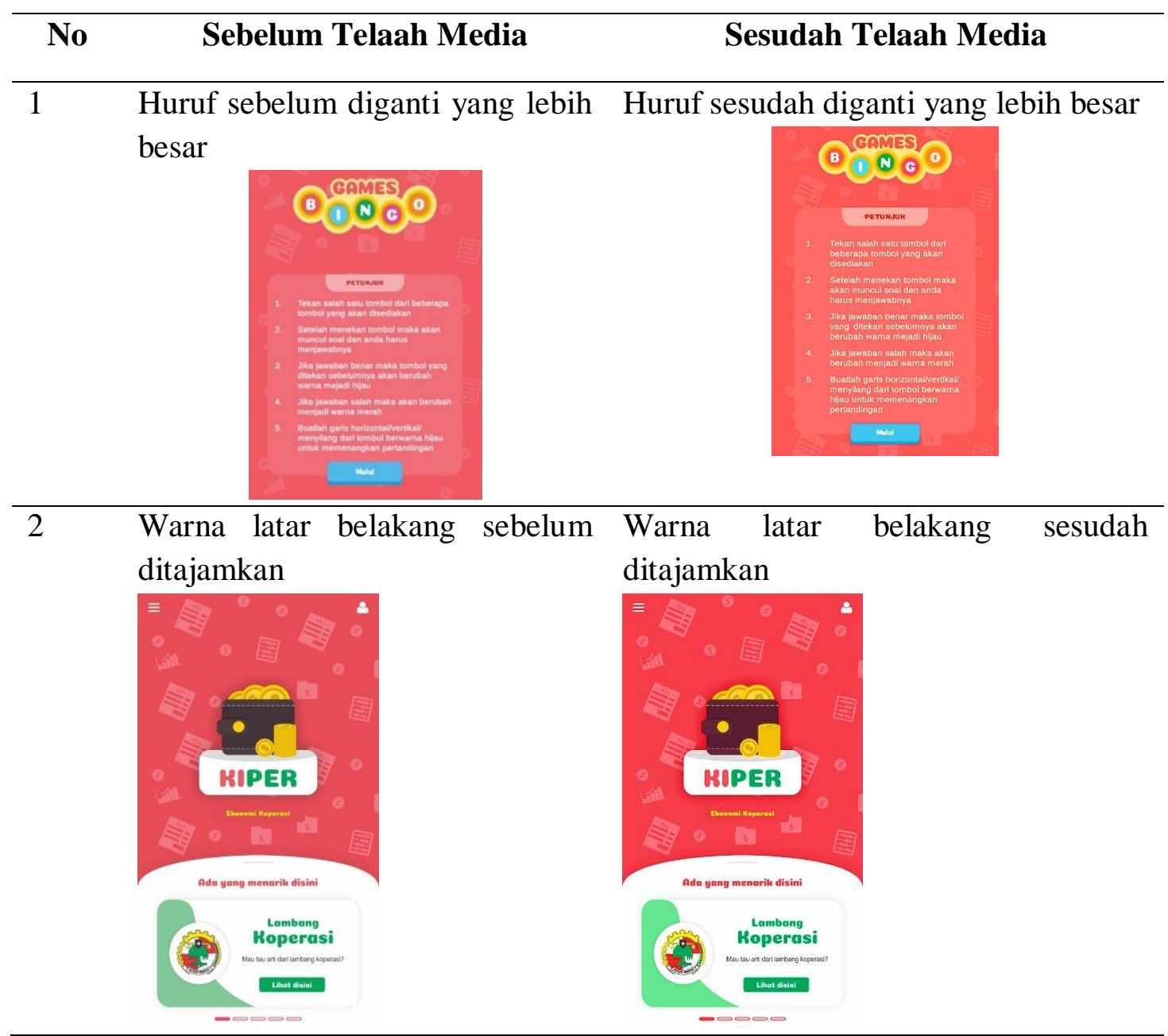

Tabel 4. Hasil Telaah Ahli Media

3. Hasil Telaah Evaluasi

Penilaian berupa telaah dan validasi dari ahli evaluasi dijadikan pedoman peneliti untuk memperbaiki soal evaluasi yang dikembangkan. Saran perbaikan dan komentar dari ahli media sebagai berikut :

\begin{tabular}{cc}
\hline No & \multicolumn{1}{c}{ Komentar dan Saran Perbaikan } \\
\hline 1 & - Cek lagi tentang kesesuaian antara indikator soal \\
& dengan soal \\
& - Cek kata kerja operasional dalam indikator soal \\
& - Hindari penggunaan pertanyaan yang bersifat \\
& "kecuali" dan "yang bukan" \\
\hline Tabel 5. Telaah Evaluasi \\
\hline
\end{tabular}




\begin{tabular}{|c|c|c|}
\hline No & Komentar & an Saran Perbaikan \\
\hline No & $\begin{array}{c}\text { Sebelum Telaah } \\
\text { Media }\end{array}$ & Sesudah Telaah Media \\
\hline 1 & $\begin{array}{lr}\text { Peserta } & \text { didik } \\
\text { mampu peserta } \\
\text { didik mampu } \\
\text { menyebutkan } \\
\text { Negara pendirian } \\
\text { koperasi dunia } \\
\text { - Negara mana } \\
\text { yang mendirikan } \\
\text { koperasi pertama } \\
\text { kali ... }\end{array}$ & $\begin{array}{l}\text { Peserta didik mampu } \\
\text { mengidentifikasi } \\
\text { koperasi } \\
\text { - Negara yang mendirikan } \\
\text { koperasi pertama kali } \\
\text { adalah ... }\end{array}$ \\
\hline 2 & $\begin{array}{l}\text { Peserta didik } \\
\text { mampu } \\
\text { menjelaskan } \\
\text { membedakan } \\
\text { perangkat } \\
\text { organisasi koperasi } \\
\text { sekolah }\end{array}$ & $\begin{array}{l}\text { Peserta didik mampu } \\
\text { mengidentifikasi berakhirnya } \\
\text { keanggotaan koperasi sekolah }\end{array}$ \\
\hline 3 & $\begin{array}{l}\text { Berikut ini } \\
\text { merupakan asal dan } \\
\text { modal pinjaman, } \\
\text { kecuali ... }\end{array}$ & $\begin{array}{l}\text { Sebutkan modal pinjaman } \\
\text { koperasi.... }\end{array}$ \\
\hline
\end{tabular}

Tabel 6. Hasil Telaah Evaluasi

\section{Kelayakan Aplikasi Mobile Learning Bersistem Operasi Android Sebagai Media Pembelajaran Ekonomi}

Kelayakan aplikasi mobile learning bersistem operasi ini diukur berdasarkan validasi para ahli, yang meliputi ahli materi dan media. Hasil validasi para ahli berupa data angka dan dianalisis ke dalam bentuk kalimat. Validasi pada materi dari komponen isi diperoleh persentase 98\% dan dikatakan "Sangat Layak". Menurut Riduwan (2018) kriteria kelayakan media dikatakan "Layak" apabila memperoleh persentase lebih dari 61\%. Hal ini mencakup materi yang lengkap dan sesuai dengan tuntutan KD dan KI.

Pada komponen kelayakan media diperoleh persentase sebesar $89 \%$ dan dikatakan "Sangat layak". Menurut Riduwan (2018) kriteria kelayakan media dikatakan "Layak" apabila memperoleh persentase lebih dari $61 \%$.

Pada komponen kelayakan evaluasi diperoleh persentase sebesasar $80 \%$ dan dikatakan "Sangat Layak". Menurut Riduwan (2018) kriteria kelayakan media dikatakan "Layak" apabila memperoleh persentase lebih dari $61 \%$. Hal ini dikarenakan komponen evaluasi butir soal media yang dikembangkan sudah mencapai indikator pembelajaran. 


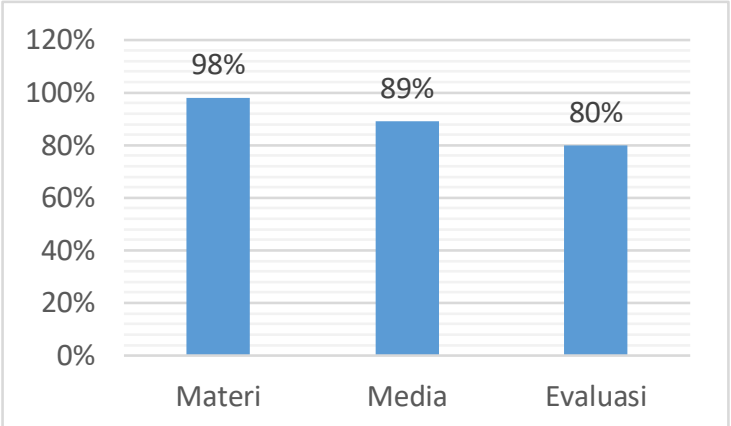

Hasil persentase rata-rata dari keseluruhan kelayakan media yang dikembangkan ini sebesar $89 \%$ dan dapat dikatakan "Sangat Layak". Menurut Riduwan (2018) kriteria kelayakan media dikatakan "Layak" apabila memperoleh persentase lebih dari $61 \%$. Persentase ini didapatkan dari rerata semua komponen.

Berdasarkan hasil validasi yang diperoleh disimpulkan bahwa produk yang dihasilkan yakni berupa aplikasi mobile learning bersistem operasi dikatakan "Sangat Layak" digunakan dalam proses uji coba serta pembelajaran ekonomi.

\section{Respons Peserta Didik Terhadap Aplikasi Mobile Learning untuk Meningkatkan Hasil Belajar Peserta Didik pada Mata Pelajaran Ekonomi}

Respons peserta didik dikembangkan melalui angket yang berupa 10 item pertanyaan dengan cakupan komonen kelayakan isi dan tujuan pada aplikasi mobile learning, komponen kelayakan instruksional pada aplikasi mobile learning, dan komponen kelayakan teknis pada aplikasi mobile learning. Dalam angket tersebut peserta didik disediakan angket yang berisi pertanyaan dan jawaban dengan memilih jawaban "YA" nilai 1 atau "TIDAK" nilai 0. Hasil data respons dari peserta didik ini akan dianalisis dengan deskriptif kuantitatif dimana data yang berupa angkat nantinya akan dianalisis menjadi kalimat.

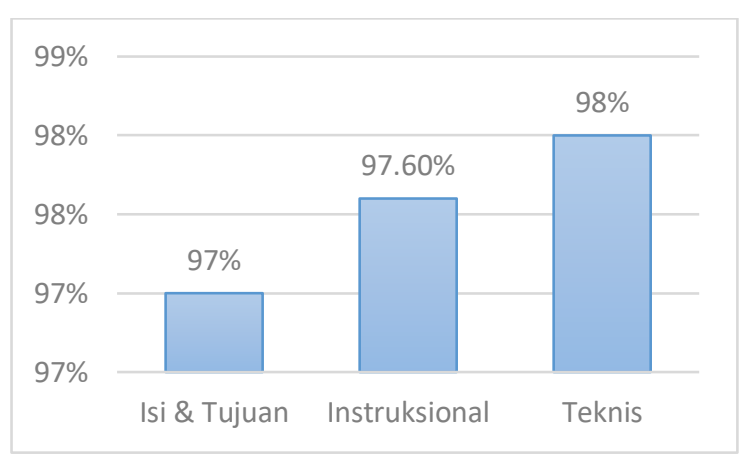

Rerata respons peserta didik memperoleh persentase 97,53\% dan dikatakan "Sangat Baik" dengan rincian sebagai berikut : aspek isi dan tujuan aplikasi mobile learning sebesar 97\%, aspek instruksional sebesar 97,6\%, dan aspek teknis sebesar 98\%. Dari hasil angket peserta didik tersebut maka dapat diartikan bahwa aplikasi mobile learning dikatakan memiliki manfaat bagi peserta didik dalam meningkatkan keterampilan, mendorong minat dan hasil belajar peserta didik karena memperoleh presentase lebih dari $61 \%$ (Riduwan, 2018). Martono, dkk (2014) dalam penelitiannya menyatakan bahwa $95 \%$ respons peserta merasakan kemudahan dalam penggunaan aplikasi mobile learning besistem operasi android. 


\section{Hasil Belajar Peserta Didik Kelas X IPS 1 SMAN 1 Gedangan Setelah Penerapan Media Pembelajaran Aplikasi Mobile learning Pada Mata Pelajaran Ekonomi}

Hasil belajar peserta didik diperoleh dari pretest dan postest. Desain uji coba digunakan dalam penelitian ini yaitu menggunakan Pretes-postest Control Group Design. Uraian dari data hasil belajar kelompok eksperimen dan kelompok kontrol yaitu pertama rerata hasil pretest kelompok kontrol sebesar 66,44 lebih rendah dari kelompok eksperimen yakni 70,22. Kedua rerata hasil postest kelompok eksperimen sebesar 84 yang lebih tinggi daripada kelompok kontrol sebesar 79,17. Ketiga hasil ketuntasan klasikal dari nilai pretest pada kelompok eksperimen dan kontrol sama sama 27,77\%. Keempat hasil ketuntasan klasikal postest pada kelompok eksperimen telah tercapai sebesar 94,44\% dan kelompok kontrol belum tercapai karena hanya memperoleh sebesar 66,66\%. Serta yang kelima yaitu hasil belajar kelompok eksperimen mengalami peningkatan gain score 0,44 kriteria sedang, lain hal nya kelompok kontrol alami sedikit kenaikan memperoleh gain score sebesar 0,3 dengan kriteria sedang (Munandar, 2018).

Penelitian dilanjutkan analisis uji normalitas, uji homogenitas, dan uji t. hasil analisis ditampilkan dalam bentuk tabel berikut.

\begin{tabular}{|c|c|c|c|c|c|c|c|}
\hline & \multirow{2}{*}{ Kelas } & \multicolumn{3}{|c|}{ Kolmogorov-Smirnova } & \multicolumn{3}{|c|}{ Shapiro-Wilk } \\
\hline & & Statistic & df & Sig. & Statistic & df & Sig. \\
\hline \multirow[t]{4}{*}{$\begin{array}{l}\text { Hasil } \\
\text { Belajar }\end{array}$} & $\begin{array}{l}\text { Pretest } \\
\text { Kontrol }\end{array}$ & .172 & 18 & .169 & .884 & 18 & .030 \\
\hline & $\begin{array}{l}\text { Posttest } \\
\text { Kontrol }\end{array}$ & .142 & 18 & $.200^{\circ}$ & .948 & 18 & .389 \\
\hline & $\begin{array}{l}\text { Pretest } \\
\text { Eksperi } \\
\text { men }\end{array}$ & .120 & 18 & $.200^{\circ}$ & .958 & 18 & .564 \\
\hline & $\begin{array}{l}\text { Posttest } \\
\text { Ekseri } \\
\text { men }\end{array}$ & .171 & 18 & .173 & .945 & 18 & .349 \\
\hline
\end{tabular}

Tabel 7. Hasil uji Kolmogorov-Smirnov

Berdasarkan hasil output yang diperoleh menggunakan uji Kolmogorov-Smirnov pada Sig pretest kelompok eksperimen mendapatkan 0,200 sedangkan kelompok kontrol mendapatakan 0,169. Pada postest kelompok eksperimen mendapatkan 0,173 dan kelompok kontrol mendapatkan 0,200. Kedua kelompok mempunyai nilai signifikan yang lebih besar dari 0,05. Dapat disimpulkan bahwa data terdistribusi normal (Arsyad \& Lestari, 2020).

\begin{tabular}{ll|rrrrr} 
& & \multicolumn{1}{c}{$\begin{array}{c}\text { Levene } \\
\text { Statistic }\end{array}$} & df1 & df2 & Sig. \\
\hline Hasil & Based on Mean & 1.374 & 3 & 68 & .258 \\
Belajar & Based on Median & 1.127 & 3 & 68 & .344 \\
& Based on Median and & 1.127 & 3 & 55.7 & .346 \\
& with adjusted df & & & 71 & \\
& Based on trimmed & 1.373 & 3 & 68 & .258 \\
& mean & & & & \\
\hline
\end{tabular}

Tabel 8. Hasil uji homogenitas 
Berdasarkan hasil output yang diperoleh dari uji homogenitas diperoleh taraf signifikan (Sig) based on mean adalah 0,258 > 0,05. Sehingga dapat disimpulkan bahwa kelompok eksperimen dan kelompok kontrol memiliki varian yang sama atau bersifat homogen (Ningsih, Misdalina, \& Marhamah, 2017) (Munandar, 2018).

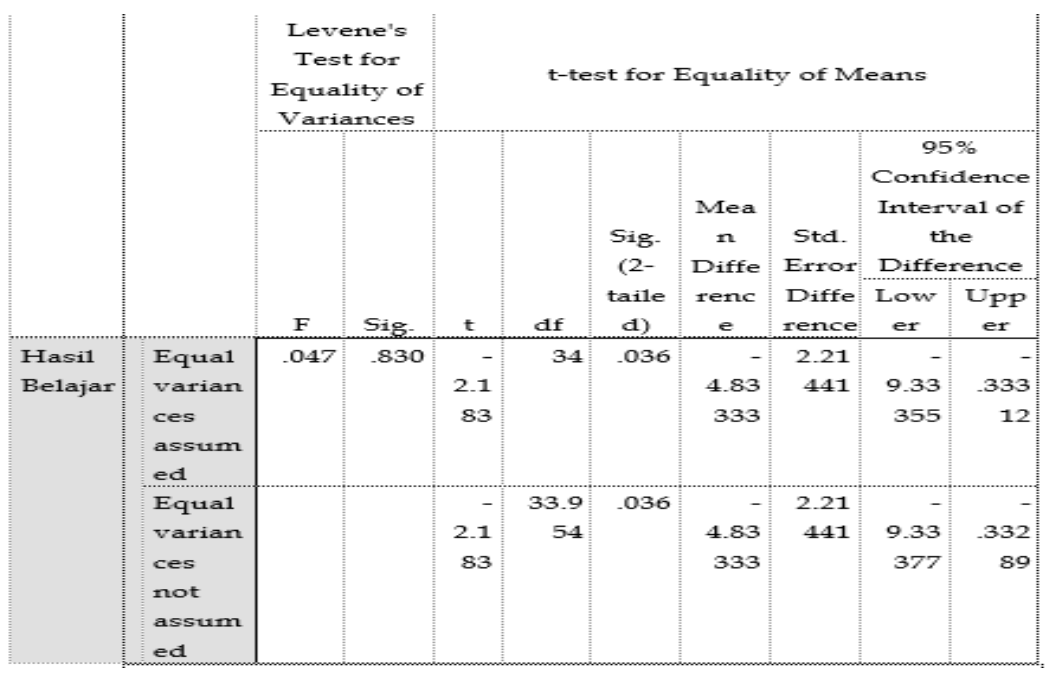

Tabel 9. Hasil uji $\mathrm{t}$

Tahap selanjutnya dilakukan uji t-test gunakan spss 25. Hasil dari uji t menunjukan bahwa terdapat pengaruh aplikasi mobile learning. Hal ini dilihat hasil uji t pada Sig(2-tailed) sebesar $0,036<0,05$, maka dapat disimpulkan $\mathrm{H}_{0}$ ditolak sedangkan $\mathrm{H}_{1}$ diterima. Terdapat perbedaan rata - rata hasil belajar peserta didik pada kelompok eksperimen dan kelompok kontrol maka dapat dinyatakan bahwa mobile learning efektif digunakan peserta didik dalam proses pembelajaran (Rahmawati \& Mukminan, 2017).

\section{Simpulan}

Berdasarkan penelitian pengembangan aplikasi mobile learning bersistem operasi android sebagai media pembelajaran ekonomi adalah sebagai berikut : 1. Kelayakan aplikasi mobile learning bersistem operasi android sebagai media pembelajaran ekonomi dilihat dari aspek kelayakan materi, media dan evaluasi butir soal diperoleh hasil sebesar $89 \%$ dengan kategori sangat layak untuk digunakan dalam proses pembelajaran. 2. Berdasarkan hasil penelitian mendapatkan respons yang sangat baik dari peserta didik dan telah memenuhi kriteria kelayakan dengan mendapatkan hasil sebesar 97,53\% yang berarti sangat baik.3. berdasarkan hasil penelitian terdapat hasil belajar peserta didik yang menggunakan aplikasi mobile learning (kelompok eksperimen) dengan yang tidak menggunakan aplikasi mobile learning (kelompok kontrol), dimana hasil belajar kelompok eksperimen lebih besar dari kelompok kontrol.

\section{Referensi}

Aisyah, Jaenudin, R., \& Koryati, D. (2017). Analisis Faktor Penyebab Rendahnya Hasil Belajar Peserta Didik Pada Mata Pelajaran Ekonomi di SMA Negeri 15 Palembang. Jurnal Profit.

Alhafidz, M. R. L., \& Haryono, A. (2018). Pengembangan mobile learning berbasis android 
sebagai media pembelajaran ekonomi. Jurnal Pendidikan Ekonomi, 11(2), 118-124.

Arsyad, A. (2014). Media Pembelajaran. Jakarta: Raja Grafindo Persada.

Arsyad, M. N., \& Lestari, D. E. G. (2020). Efektifitas Penggunaan Media Mobile Learning Berbasis Android Terhadap Hasil Belajar Mahasiswa IKIP BudiUtomo Malang. Jurnal Agastya.

Chryssa. (2016). Android Programming Cookbook. Exelixis Media.

Darmawan, D. (2016). MOBILE LEARNING Sebuah Aplikasi Teknologi Pembelajaran. Jakarta: RajaGrafindo Persada.

Delialioğlu, Ö., \& Alioon, Y. (2014). Student Preferences For M-Learning Application Characteristics. 10th International Conference Mobile Learning 2014.

Handayani, R. D. (2016). Pengembangan Bahan Ajar Elektronik Berbasis Mobile-Learning Pada Mata Kuliah Optik di FKIP Universitas Jember.

Kurniawati, I. D., \& Nita, S. (2018). Media Pembelajaran Berbasis Multimedia Interaktif untuk Meningkatkan Pemahaman Konsep Mahasiswa. Jurnal of Computer and Information Technology.

Lubis, I. R., \& Ikhsan, J. (2015). Pengembangan Media Pembelajaran Kimia Berbasis Android untuk Meningkatkan Motivasi Belajar dan Prestasi Kognitif Peserta Didik SMA. Jurnal Inovasi Teknologi Pendidikan Ipa.

Martono, K., Teguh, K., \& Nurhayati, O. D. (2014). Imlementation of Android Based Mobile Learning as A Flexible Leaning Media. 11(3).

Munandar, I. (2018). Pengaruh Penerapan Pembelajaran MOBILE LEARNING Terhadap Peningkatan Hasil Belajar Ekonomi. SOSIO DIDAKTIKA: Social Science Education Journal.

Ningsih, Y. L., Misdalina, \& Marhamah. (2017). Peningkatan Hasil Belajar dan Kemandirian Belajar Metode Statistika Melalui Pembelajaran Blended Learning. Al-Jabar: Jurnal Pendidikan Matematika.

Quinn, C. N. (2012). The Mobile Academy: mLearning For Higher Education. San Fransisco: Jossey-Bass.

Rahmawati, E. M., \& Mukminan. (2017). Pengembangan M-Learning untuk Mendukung Kemandirian dan Hasil Belajar Mata Pelajaran Geografi. Jurnal Inovasi Teknologi Pendidikan.

Riduwan. (2018). Skala Pengukuran Variabel-variabel Penelitian. Bandung: Alfabeta.

Roesminingsih, M. V. (2016). Teori dan Praktek Pendidikan. Surabaya: Lembaga Pengkajian dan Pengembangan Ilmu Pendidikan Fakultas Ilmu Pendidikan Unesa.

Safaat H, N. (2012). ANDROID Pemrograman Aplikasi Mobile Smartphone dan Tablet PC Berbasis Android. Bandung: INFORMATIKA.

Sutarsih, T., \& Hassyati, A. N. (2018). Penggunan dan Pemanfaatan Teknologi Informasi dan Komunikasi (P2TIK) Sektor Pendidikan 2018. Jakarta: BPS RI.

Wahyono, H. N. (2018). Pengembangan Media Pembelajaran Ekonomi Interaktif Berbasis Android Sebagai Upaya Peningkatan Aktivitas dan Hasil Belajar Siswa. 